\title{
NONET AND SELZNICK'S RESPONSIVE LAW CONCEPT IN A HISTORICAL PHILOSOPHY PERSPECTIVE
}

\author{
Agam Ibnu Asa*1, Misnal Munir², Rr. Siti Murti Ningsih ${ }^{3}$ \\ ${ }^{1} \mathrm{PhD}$ Student in Legal Philosophy, Faculty of Philosophy, Universitas Gadjah Mada, Indonesia \\ ${ }^{2}$ Department of Western Philosophy, Faculty of Philosophy, Universitas Gadjah Mada, Indonesia \\ ${ }^{3}$ Department of Western Philosophy, Faculty of Philosophy, Universitas Gadjah Mada, \\ Indonesia \\ agam.ibnu.a@mail.ugm.ac.id
}

\begin{abstract}
The responsive laws of Nonet and Selznick's thinking became one of the results of conceptual ideas about the laws that are elaborated periodically. The development of responsive law may be less comprehensive when it has not been found the historical fundamental aspects on which it is focused. It is thus important to study the concept of Nonet and Selznick's responsive legal philosophically. The method in this research is the philosophical method. The results of this study include: first, the development of law in Nonet and Selznick's view is divided into three periods of repressive law, autonomous law, and responsive law. Second, Nonet and Selznick's responsive law when reviewed in historical perspective gained an understanding that responsive law exists from a constantly creative legal subject by looking at legal issues and realities in an increasingly complex society, and responsive law is a law that has always served as part of cultural dynamics.
\end{abstract}

Keywords: Philosophy; Responsive Law; Justice

\begin{abstract}
Abstrak
Hukum responsif pemikiran Nonet dan Selznick menjadi salah satu hasil ide konseptual tentang hukum yang diuraikan secara periodik. Perkembangan hukum responsif tersebut kiranya kurang komprehensif ketika belum diketemukan aspek fundamental historis yang dijadikan tumpuanya. Dengan demikian penting kiranya untuk mengkaji konsep hukum responsif Nonet dan Selznick secara filosofis. Metode dalam penelitian ini yaitu metode filsafati. Hasil penelitian ini diantaranya: pertama, perkembangan hukum dalam pandangan Nonet dan Selznick dibagi menjadi tiga periode hukum represif, hukum otonom, dan hukum responsif. Kedua, hukum responsif Nonet dan Selznick ketika ditinjau dalam perspektif sejarah diperoleh pemahaman bahwa hukum responsif ada dari subjek hukum yang terus kreatif dengan melihat masalah hukum dan realitas dalam masyarakat yang semakin kompleks, serta hukum responsif merupakan hukum yang selalu berfungsi sebagai bagian dari dinamika budaya.
\end{abstract}

Kata kunci: Filsafat; Hukum Responsif; Keadilan

\section{A. Introduction}

Man is a creature that plunders, in his life man is enveloped with changes that exist with various elements that follow it. The fact that distinguishes man from other living things is his 
ability to participate in the existence of man himself. Man has a historical consciousness that makes him able to interpret his history that covers the past, present, and future. This historical awareness is the characteristic of humans that distinguishes from other living things, with humans able to determine and design the direction of their own lives independently, taking into account aspects of their history. Human life is filled with various dynamics that exist, man one with another living in a place and at the same time, making it filled with various interests that exist. This certainly makes fulfilling or fulfilling every interest and need that is clearly limited. The consequence that arises is in a sociality when everyone has different interests and needs, so that there is no conflict of interest, then the rules of the game are needed to regulate the path of sociality in society, in order to create order, tranquility, and welfare.

Societies with a wider scope as the state certainly need more complex mechanisms. This is one of them by making a rule that regulates all kinds of lives of its people so that every right is protected. Basically in every community already has rules or customary laws that already live in the community. The problem is that the rules are still not strong enough to regulate and force them to obey the rules, therefore it takes a law that has strong legitimacy and has strict sanctions to realize legal ideals. Positive law as a law that applies legally in a country has a fairly rapid development. Historically law can be categorized into three stages, namely repressive law, autonomous law, and responsive law. Law as part of the cultural product of man is inseparable from the historical aspects of man himself. The development and dynamics of law always follow the development and needs of increasingly complex human beings.

Therefore in this case the author is interested in analyzing how the development of legal history. In this case the author tried to analyze the development of the law according to Nonet and Selznick who divided the law into three periods, namely repressive law, autonomous law, and responsive law. Responsive law is one type of law that is stuttered by two figures, Philippe Nonet and Philipe Selznic'k. Responsive law offers a paradigm in looking at the law by emphasizing the substantive fairness aspects of the law. Responsive law emerged as the antithesis or attempt at scientific criticism of the increasingly precipitous doctrine of legalism. Legalism focuses on procedural law and not substantial law. What happens is that the law no longer reflects justice in society, while the law is limited to rigid rules, where it often hurts people's sense of justice.

The author chooses responsive law as the object of study, because the author considers that this responsive legal paradigm is a breakthrough in the conceptual and practical field of law that needs to be developed. The author is interested in further introducing that the law is not merely a textual law but the law must also be contextual by putting forward aspects of substantive justice. The law was created for man, not man, who must then be subjected to the 
law. This means that responsive law is an attempt to resuscitate people who have been indoctrinated by overly positivistic laws, where they at least eliminate the subtsantive aspects of the law itself. Responsive law in this case maps out the gradual development of responsive law from the development of repressive, autonomous, and evolving laws to responsive laws. According to the authors Nonet and Selznick's thoughts on law are interesting to peel away even further because each period of legal sasi has its own historical aspects, and it influences each other in the development of legal periodization. The perspective used in this paper is Joseph Arnorld Toynbee's thoughts on civilization. This thought is in our opinion relevant to dissecting and explaining how historic a law is in human life itself. With this, the author pulls some problem formulations that will be answered in the paper description below;Problem formulation: (1). How did the law responsive evolve according to Philippe Nonet and Philipe Selznic'k? (2). How is the historicity of responsive law reviewed in Joseph Arnorld Toynbee's philosophy of history?

\section{B. Method}

This research is a historically factual study of figures. ${ }^{1}$ More specifically this research as philosophical research that discusses the concept of legal thought of a figure studied with the approach of historical philosophy. The study model conducted in this study with the literature study. The material object in this study is the concept of responsive law according to Philippe Nonet and Philip Selznic'k which will be studied using the formal objects of historical philosophy, specifically the historicity of Joseph Arnorld Toynbee's. The responsive legal thinking of Nonet and Selznic'k is viewed philosophically, as far as providing a mission vision of man and its nature.

The step in the study began with an inventory of the work of Nonet and Selznic'k figures related to responsive law. The method used is a philosophical interpretation to explore and reflect the thoughts of Nonet and Selznic'k in order to gain a deep understanding of the legal types of Nonet and Selznic'k versions. Interen coherence as the next method is used in order to provide precise intrepetation of the mind of the character, all concepts studied according to harmony. The method of heuristic further used to look at material objects with a new approach, the philosophy of history, in order to find a new understanding of the historicity of responsive laws in a human civilization.

1 Anton Bakker dan Achmad Charris Zubair, A.C, Metodologi Penelitian Filsafat, (Yogyakarta: Kanisius, 1990). 


\section{Result and Discussion}

\section{The Development of Responsive Law}

Responsive law is a model or theory initiated by Nonet-Selznic'k amid scathing NeoMarxist criticism of liberal legalism. Liberal legalism presupposes law as an independent institution with an objective, impartial, and completely autonomous system of rules and procedures. The icon of liberal legalism is legal autonomy. The most obvious form of autonomy is the rule of law regime. With its autonomous character, it is believed that the law can control repression and maintain its own integrity. ${ }^{2}$ The legal type proposed by Nonet and Selznic'k stems from the first phase of repressive laws oriented toward the legitimacy of power, but they think this type is weak in relation to its unstable legitimacy. Then, tie the second autonomous law, promising a stable institutional order. Autonomous law is central in the development of law, because it promises certainty. But autonomous law has limitations that give rise to demands for a responsive law that promotes flexibility in the political community. The legal type proposed by Nonet and Selznic'k stems from the first phase of repressive laws oriented toward the legitimacy of power, but they think this type is weak in relation to its unstable legitimacy. Then, tie the second autonomous law, promising a stable institutional order. Autonomous law is central in the development of law, because it promises certainty. But autonomous law has limitations that give rise to demands for a responsive law that promotes flexibility in the political community. ${ }^{3}$

The three types of laws offered by Nonet and Selznick put forward the classical paradigms of legal theory. Philosophical viewpoints such as legal positivism or legal realism may reflect the conditions of conflict when formulated as common theories of the rule of law. These perspectives can be better combined and understood if they are seen as the cause of different classifications of legal experience. ${ }^{4}$ Multi-perspective in the application of the law will be very helpful in sorting out and considering substantive aspects in the law itself. First, in the development of the law according to Nonet and Selznick was anointed first about how repressive law expands.

According to Nonet and Selznick ${ }^{5}$ Repressive law exists first, in the sense that it solves the fundamental problem of building a political order, a condition in which without the rule of law

2 Sulaiman, Hukum Responsif: Hukum Sebagai Institusi Sosial Melayani Kebutuhan Sosial dalam Masa Transisi (Responsive Law: Law as a Social Institution to Servive of Social Need in Transition), Jurnal Hukum Samudra Keadilan, Vol. 9, No. 2, Cet. 2014.

3 Philippe and Philip Selznic'k, Toward Responsive Law: Law and Society in Transition, (London and New York: Routledge, 2017).

4 Philippe Nonet and Philip Selznic'k, Diterj. Raisul Muttaqien dari Toward Responsive Law: Law and Society in Transition ke (Hukum Responsif Philippe Nonet dan Philip Selznic'k), (Bandung: Penerbit Nusa Media, 2008).

5 Ibid, hlm 29 . 
and the political system it cannot move towards higher conditions. Power completely ignores the public interest, by denying the meaning of social legitimacy as a source of legitimacy of power then the government is categorized as repressive. A repressive government will turn into a repressive regime, and rely heavily on the character of power exercised. A repressive regime is one that puts all interests in danger, and in particular interests that are not protected by the prevailing system in terms of privilege and power, but in some ways and to some degree, any repressive political order. ${ }^{6}$

Repressive legal characters, namely ${ }^{7}$ :

1. Legal institutions directly accessible to political forces; the law is identified equal to the state and placed under the objectives of the state (raison d'etat).

2. The lasting of an authority is the most important matter in the administration of law. In the "official perspective" awakened, the benefit of the doubt enters the system, and administrative convenience becomes a heavy point of concern.

3. Specialized control agencies, such as the police, become independent centers of power; They are isolated from social contexts that function to soften, and are able to resist, political authority.

4. A "dual law" regime institutes class-based justice by consolidating and legitimizing social subordination patterns.

5. Criminal law reflects dominant values; Legal moralism will prevail.

Second, autonomous law becomes a type of law as a continuation of repressive laws. Autonomous law arises because of a weakened belief in repressive laws and the various problems they cause, which necessitate the option of applying alternative legal typology. This expectation triggers public action and power in finding a new, more objective and proportionate legal consensus. The state is the highest subject in the exercise of power. Repressive laws tend to be oriented towards one aspect of power as a focus in carrying out the law. Power tends to interfere with all aspects of the law, both in the legislative process, and the law enforcement process on the ground. The muscle of government becomes possible to be abused in such actions. So on the basis of arbitrariness in repressive law then gave rise to autonomous legislation as a form of anti-thesis against repressive law. ${ }^{8}$

6 Ahmadi, Kontroversi Penerapan Hukum: Telaah Sintesa Hukum Represif, Hukum Otonom dan Hukum Responsif, Jurnal, Al-Adl, Vol. 09, No. 01, 2016, hlm 29.

7 Nonet and Selznic'k, 2008, Op.cit, hlm 37.

8 Agam Ibnu Asa, Peran Mahkamah Konstitusi Mewujudkan Keadilan Substansial dalam Perspektif Hukum Responsif Philippe Nonet dan Philip Selznic'k (Studi Kasus Putusan Mahkamah Konstitusi Nomor 45/PHPU.D-VIII/2010, (Yogyakarta: Tesis Filsafat Universitas Gadjah Mada, 2020), hal. 46. 
Nonet and Selznick in their book say that: ${ }^{9}$

"With the emergengence of autonomous law, the legal order becomes a resource for taming repression. Historically, that achievent may be claimed for what is celebrated as the "Rule of Law". This prhase cannotes more than the mere existence of Law. It refers to a legal and political aspiration, the creation of "a government of laws and not of men." In that sense, the rule of law is born when legal institutions acquire enough in dependent authority to impose standards of restraint on the exercise of governmental power".

Autonomous law emerged as a legal order that sought to tame repressive laws. Autonomous law is also often known as the "rule of law". The term refers not only to the existence of law but also to legal and political aspirations, by creating a government based on law and not based on people or power. Autonomous law will be born if legal institutions gain sufficiently independent authority in imposing standards of control in the exercise of government power. ${ }^{10}$

Nonet and Selznick ${ }^{11}$ explain the consequences of autonomous law:

"In effect, a historic bargain is struck: Legal institutions purchase procedural autonomy at the price of substantive subordination. The political community delegates to the jurists a limited authority to be exercised free of political intrusion, but the condition of that immunity is that they remove themselves from the formation of public policy. Those are the terms on which the judiciary wins its "independence.

The above view wants to assert that autonomous law has an impact on historical bargaining i.e. a legal institution essentially gains procedural autonomy on the condition that it sacrifices the autonomy of substance. The political community conducts delegations of jurists to act free from political intervention. The condition of this right to immunity is that jurists are required to abstain from the formation of public policy. That's what shows that the judiciary has a strong dependency. Thus autonomous law attempts to neutralize the law from political interference with the practice of law and lawmaking itself, thereby creating legal independence that upholds integrity.

Third, responsive law as a type of law that is considered a type of law that hassed a period of evolution that is quite mature. According to Asa ${ }^{12}$ Responsive law is an ongoing project undertaken by modern law. Legal realism also provides the view that their main goal is to make the law more responsive to social needs. The search for the formulation of law is desirable - the unstoppable ideal of the discovery of autonomous law that tends to strengthen institutional positions. The continuation of the search for legal potential that typologically reflects

\footnotetext{
9 Nonet and Selznic'k, 2017, Op.cit, hlm 53.

10 Agam Ibnu Asa, Loc.cit. hal.46-47.

11 Nonet and Selznic'k, 2017, Op.cit, hlm 58.

12 Agam Ibnu Asa, Op.cit. hal.46-51
} 
broader justice, continues to exhale and ultimately gives rise to the typology of a third law, responsive law. The wandering search for responsive law is an ongoing activity of modern legal theory.

The development of responsive law is the result of the evolution of the wanderings of legal theory in an attempt to offer an effective way out of the order and achievement of the legal objectives themselves.The patterns and motives of responsive law are very different from repressive, and autonomous types of laws. Accommodative nature is the hallmark of responsive law and it is not owned by the other two types of laws. Its accommodating nature indicates a willingness to meet social expectations. The application of responsive law in a country will greatly affect how the character is displayed in the organization of legal institutions, legal materials and legal culture. This tradition of legal development has taken a different and more constructive path to achieving legal certainty as an instrument of state management. Here are some typical characters of responsive law.

The three types of laws described earlier are repressive, autonomous, and responsive, and can be understood as three responses to the dilemma that arises between openness and integrity. Nonet and Selznick explain that ${ }^{13}$ :

"Repressive, autonomous, and responsive law can be understood as three responses to the dilemma of integrity and openness. The hallmark of repressive law is passive, opportunistic adaptation of legal institutions to the social and political environment. Autonomous law is a reaction against that indiscriminate openness. Its overriding preoccupation is the preservation of institutional integrity. To that end, law insulates itself, narrows its responsibilities, and accepts a blind formalism as the price of integrity A third type of law strives to resolve that tension. We call it responsive, rather than open or adaptive, to suggest a capacity for responsible, and hence discriminate and selective, adaptation. A responsive institution retains a grasp on what is essential to its integrity while taking account of new forces in its environment".

Responsive law is the third type of law that seeks to overcome existing tensions. Responsive law cannot be said to be an open or adaptive legal model alone. The reason is that responsive laws seek to demonstrate responsible adaptability. Responsiveness is a selective and non-haphazard adaptive law. The development of these three types of laws according to Nonet and Selznick apparently has a process of historical evolution involving cyclical changes and political and social dynamics that exist in society. So it takes a historical point of view or perspective that can be used to dissect and analyze the historical aspects of the concept of responsive law according to Nonet and Selznick. Joseph Arnold Toynbe's thoughts on Historicity may be relevant to use as viewpoints in dissecting this concept of responsive law.

13 Nonet and Selznic'k, 2017, Op.cit, hlm 76-77. 
This is because in line with the ever-changing movement of legal developments from the simplest stage to the simplest stage.

\section{Joseph Arnorld Toynbee's Philosophy of History}

Arnold Toynbee, or more fully Arnold Joseph Toynbee, is the nephew of an economic historian of the same name, Arnold Toynbee. In his various books his name is often written without $\mathrm{J}$ (Joseph). He was a British historian, better known for his views on the past as a succession of civilizations than political entities. He was educated at Winchester College and Balliol College, Oxford. From 1912 to 1915 he was an undergraduate and tutor in ancient history at Balliol College. He served as professor of Modern Greek and Byzantine history at the University of London from 1919 to $1924 .^{14}$

Arnold J. Toynbee in "The Study of History": "The rise and fall of a civilization depend on the concept of "Challenge and Response". The rise of a civilization depends on the concept of "Challenge and Response". In other words, a civilization that is able to answer the challenges and demands of the times, it will still exist and survive and even develop. On the contrary, a civilization that is unable to properly answer the demands and challenges of its time, it will collapse and may disappear altogether. ${ }^{15}$

Toynbee emphasized the influence of cultural actors who can make the culture progress. Looking at the explanation of the challenges and answers above, it can be said that in addition to actors, the magnitude of the challenge can be a trigger factor (triger) for cultural development. For Toynbee, civilization is a movement or process, not a condition, a journey not a port. Civilization is a movement not a condition, a voyage not a harbour. ${ }^{16}$ Society and individuals are described by Toynbee as a system of relationships between humans who are not only individuals but also social beings. The historical reality of human social ability, by constantly developing it in ideas and concepts, until Aristotle's view of social beings becomes a kind of repetition in the study of historical philosophy. ${ }^{17}$ The two elements of man and society become two things that are inseparable in a civilization.

Man and society according to Toynbe are confronted by the ever-changing or sequential currents of life that each member must solve themselves. Problems are the challenge of experiencing hard self-testing. Through hard self-testing, members of society progressively

14 Sartini, Laporan Penelitian: Inventarisasi Tokoh dan Pemikiran Tentang Perkembangan Kebudayaan, (Yogyakarta: Fakultas Filsafat UGM, 2011).

15 Mahmud Kusuma, Menyelami Hukum Progresif:Terapi Paradigmatik Bagi Lemahnya Hukum di Indonesia, (Yogyakarta: Antonylib, 2009).

16 Arnold Toynbee, Vol I-X, A Study of History, (London: Oxford University Press, 1956), hlm 58.

17 Arnold Toynbee, An Historian's Approach to Religion, (New York: Oxford University Press, 1954), hlm 14-15. 
distinguish themselves from one another. History is the history of society or civilization. Experience is the experience of civilization in which nations are participants, and they signify the relationship between parts and wholees. The power in actions proceeds from causes beyond it, operates in every part, and comprehensively operates throughout society. To interpret the passages must refer to the whole, for the whole is understood in itself. ${ }^{18}$

\section{Nonet and Selznick's Responsive Law Analysis of Historical Philosophy Perspectives}

Responsive law is a law born of cultural processes. This law came about because of the desire of the state that wants to have a legal system that is open to the aspirations of its people. The legal model proposed by Nonet and Selznick historically dates back to the first phase of repressive laws oriented toward the legitimacy of power, but they think this type is weak in relation to unstable legitimacy. This then gave rise to a type of autonomous law in which it promised a stable institutional order. In its implementation it turns out that autonomous laws have limitations that give rise to the demand for responsive laws that prioritize flexibility in the political community. In the view of responsive law, a responsive institution strongly maintains the essence of its integrity while still paying attention to or considering the existence of new forces in its environment. To do this, responsiveness reinforces the ways in which openness and integrity can sustain each other despite clashes between the two. This responsive institution regards social pressure as a source of knowledge and an opportunity to improve itself. Responsive law is synonymous with the kind of laws that are adaptive to the dynamics of culture and civilization that are not fixed.

According to Toynbee ${ }^{19}$ According to Toynbee, the creative displacement that occurs in microcosm requires adaptive modification in macrocosm to fit or align. The personal macrocosm that is changed is the macrocosm of society. The emergence of culture (not too distinguished terms culture and civilization) because the history of civilization began with challenges. The first challenge is usually a physical challenge. Difficult situations faced by humans will trigger human creativity. In this situation humans are challenged and stimulated to do something. So civilization develops because humans struggle and are able to overcome challenges. Civilization come to birth and proceed to grow by succesfully responding to succesive challenges.

Responsive law as a law that has a long evolution, can be categorized as a law born from an established civilization. Responsive law is born because of challenges to respond to all kinds

18 Arnold Toynbee, 1956, Op.cit, hlm 17-20.

19 Arnold Toynbee, 1956, Op.cit, hlm 525. 
of complex problems in society. This is as expressed by ${ }^{20}$ which states that nonet and Selznick's responsive legal theory requires that the law always has a sensitivity to the development of society, with its prominent character by offering more than just proceduraljustice oriented to justice, paying attention to the public interest and more than that, namely prioritizing substantial justice. Nonet and Seleznick argue that responsiveness is a law that promises a lasting and stable institutional order. Nonet and Selznick rejected the final and inviolable legal autonomy. Responsive law theory is a legal theory that contains a critical view. This theory holds that the law is the way to achieve the goal. Responsive characteristics mean a commitment to (law in consumer perspective). ${ }^{21}$ Therefore responsive law is born from the subject of law that continues to be creative by looking at the increasingly complex realities of law and society and if left unchecked will have a serious enough impact that can disrupt social order. Responsive law is a law that always works, because it becomes part of cultural development. This is in line with the philosophy of Progressiveism which sees culture as the result of the human mind and is known as the result of human thought. ${ }^{22}$

A culture will be born, grow and die followed by the birth of a new culture. The thing emphasized by Toynbee is the influence of cultural actors who can make the culture progress. Looking at the explanation of the challenges and answers above, it can be said that in addition to actors, the magnitude of the challenge can be a trigger factor (triger) for cultural development. For Toynbee, civilization is a movement or process, not a condition, a journey not a port. ${ }^{23}$ Responsive law as part of culture has a process direction that is always dynamic and follows the development, willingness and needs of the community for a law. So that responsive law can be considered a human historical project in the future. This is in line with Berdyaev's view in Munir ${ }^{24}$ which views that historicality is born from the consequences of future expectations. People put the future as a dream that will be strived to achieve it.

When viewed in the perspective of the Theory of Consciousness of the fullness of the history of Gadamer's thought then responsive law as a legal concept cannot simply be separated from the environmental and historical context. According to Hasanah ${ }^{25}$ the starting

20 Mahmud Kusuma, Op.cit, hlm 32.

21 Henry Arianto, Hukum Responsif dan Penegakan Hukum di Indonesia, Lex Jurnalica, Vol. 7, No. 2, Cet. 2019.

22 Agam Ibnu Asa, Pendidikan Menurut Ki Hadjar Dewantara dan Driyarkara, Jurnal Pendidikan Karakter UNY Yogyakarta, Vol. IX, No. 2, 2019.

23 Sartini, 2011, Op.cit, hlm 39.

24 Misnal Munir, Messianisme dalam Perspektif Filsafat Sejarah, Jurnal Filsafat UGM, Vol. 36, No.1, Cet. 2004.

25 Hasyim Hasanah, Hermeneutik Ontologis-Dialektis-Georg Gadamer (Produksi Makna Wayang Sebagai Metode Dakwah Sunan Kalijogo)", Jurnal At-Taqaddum, Vol. 9, No. 1, 2017. 
point of Gadamer's hermeneutic concept originated from Heidegger's phenomenology of present-at-hand making humans historical creatures. Resent is present, and at-hand is our definite attachment, which is referred to in the term Heidegger in-der-welt-sein. An interpreter and text are bound in a hermeneutic state while he or she is interpreting. That engagement gave rise to a mode of being of historicity. This is because humans are basically always attached to their cultural environment such as human practicality in in-der-welt-sein. This concept is also what makes humans into historical creatures and that is what gadamer's thesis in the development of his theory.

Responsive law is a law born because of the historical awareness of the subject of legal thinkers. There are stages that are passed in formulating the responsive law of the three stages that cannot be separated from the relatedness in the historical aspects of one another. In the first stage it is in repressive law, where man is aware of himself and the need for a law to be limited to regulating himself and others, and sometimes personal interests are still in the name of the law. Repressive laws tend to emphasize the aspect of coercion for the sake of creating certain goals. The second stage, namely autonomous law, where autonomous law is a law born of human historicality that has begun to understand the importance of the rule of law, as well as the independence of a law. This autonomous law itself provides the offer that the law must be neutral from political interference and other interests outside the law. This is as anti-thesis form of repressive law that tends to attach importance to the interference of power over the law. Autonomous law opposes that it cannot be used as a tool to achieve all kinds of interests of the legislator. Therefore the law must be restored to its nature, law as law to create public order. The law that is in the third stage is a repressive law, man as a creature who is aware of its historicity at this stage is quite aware that the law should not be enough just procedural and rigid. But the law must also be able to be contextualized with the social reality of existing society. The law must understand the values that live in society. This means that there are aspects of justice and expediency that are of concern in responsive law. Aspects of legal certainty cannot then deviate from the susbtantive aspect of a law. The main purpose of law is no longer limited to procedural law only, but law for justice and expediency. So that the law has a direction and purpose for the creation of justice and social welfare for the whole community.

Bildung in the text of Nonet and Selznic'ks Responsive Law can be seen from how the fullness of historical elements and the experience of subject thinking. Responsive law is influenced by sociological jurisprudence and legal realism. Sociological jurisprudence is a school of legal philosophy that attempts to focus on aspects of written law and unwritten law in society, while legal realism as a school of legal philosophy that attempts to focus on the empirical reality of legal facts in the field. Thus responsive law can be said to be the result of a 
dialogical relationship between sociological jurisprudence and legal realism. Responsive law is considered the ideal type of law in transition and present times. This is because this law requires openness to all kinds of legal problems in society.

Nonet and Selznick are two figures with similar historical backgrounds in looking at the law. Both intellectually and from knowledge and experience are morally almost the same. The sociological aspect becomes the knowledge of both figures to move forward to develop the concept of responsive legal thinking, both considering legal issues in this world that most appear to be the confinement of legal views in the paradigm of legal positivism. Legal positivism is considered to have overreached, causing distorted legal values. Philosophy and sociology were then offered by these two figures by concocting the thoughts of earlier figures such as the thoughts of Roscoe Pound, Holmes, and sociological and legal thinkers to be blended into the concept of responsive legal paradigms. Then related to the moral knowledge of these two figures, both focus on the morality that lives in society. Morality that has been visualized into law is not the only law that is the only law, because there is still universal morality and becomes the benchmark of the success of applicable laws in a country.

Man and society according to Toynbe are confronted by the ever-changing or sequential currents of life that each member must solve themselves. Problems are the challenge of experiencing hard self-testing. Through hard self-testing, members of society progressively distinguish themselves from one another. ${ }^{26}$ History is the history of society or civilization. Experience is the experience of civilization in which nations are participants, and they signify the relationship between parts and wholees. The power in actions proceeds from causes beyond it, operates in every part, and comprehensively operates throughout society. To interpret the passages must refer to the whole, for the whole is understood in itself. ${ }^{27}$ Thus law is responsive as part of the response to all sorts of problems that exist in society related to various practical or philosophical problems at hand. Especially in terms of justice, certainty and legal expediency. Responsive law seeks to be adaptive and open to all forms of possibilities that will occur in people's lives.

\section{Conclusion}

With the above description of the discussion of "The Responsive Law of Philippe Nonet and Philipe Selznick in the Historical Perspective of Joseph Arnold Toynbe" can be drawn some conclusions as follows: The development of law according to Nonet and Selznick is divided into three types of law. First, repressive law is a law that focuses on aspects of power. Law and

\footnotetext{
${ }^{26}$ Arnold Toynbee, 1956, Op.cit, hlm 18

27 Arnold Toynbee, 1956, Op.cit, hlm 20.
} 
politics have no limits. The law is synonymous with politics and vice versa. Often in the exercise of the law, the interference of power is so visible that the law is not neutral. Second, autonomous law as a law that wishes to challenge the thesis of repressive law. According to the autonomous law of politics and the law cannot be mixed, the law as law must be neutral. Politics is only a mechanism for the formulation of a law. When the law already has legitimacy, the politics of power must be subject to the applicable law. Autonomous law tends to emphasize aspects of procedure rather than substantive fairness. Third, the law is responsive. Responsive law is a fairly mature type of law, this type of law tries to bridge the conflict between repressive law and autonomous law. Responsive law gives emphasis to adaptive openness to people's aspirations. This law is not merely procedural but substantial justice considerations are still taken into account. Nonet and Selznick's responsive law after being analyzed with the historical philosophy of Joseph Arnold Toynbee obtained a view that responsive law is born from legal subjects that continue to be creative by looking at the increasingly complex realities of law and society and if it is left unchecked it will have a serious enough impact that can disrupt social order. Responsive law is a law that always processes as part of a culture that has a dynamic process direction by following the development, will and needs of the community for a law. Responsive law as part of the response to all kinds of problems in society related to various issues, especially related to the issue of justice, certainty and legal expediency. Responsive laws seek to be adaptive and open to all forms of possibilities that will occur in people's lives.

\section{REFERENCES}

\section{Book:}

Bakker Anton dan Zubair, A.C, Metodologi Penelitian Filsafat, Yogyakarta: Kanisius, 1990.

Kusuma Mahmud, Menyelami Hukum Progresif:Terapi Paradigmatik Bagi Lemahnya Hukum di Indonesia, Yogyakarta: Antonylib, 2009.

Nonet Philippe and Philip Selznick, Diterj. Raisul Muttaqien dari Toward Responsive Law: Law and Society in Transition ke (Hukum Responsif Philippe Nonet dan Philip Selznick), Bandung: Penerbit Nusa Media, 2008.

Nonet Philippe dan Philip Selznick, Toward Responsive Law: Law and Society in Transition. London and New York: Routledge, 2017.

Sartini, Laporan Penelitian: Inventarisasi Tokoh dan Pemikiran Tentang Perkembangan Kebudayaan, Yogyakarta: Fakultas Filsafat UGM, 2011.

Toynbee Arnold, An Historian's Approach to Religion. New York: Oxford University Press, 1954.

Toynbee Arnold, Vol I-X, A Study of History, London: Oxford University Press, 1956. 


\section{Journal:}

Ahmadi, Kontroversi Penerapan Hukum: Telaah Sintesa Hukum Represif, Hukum Otonom dan Hukum Responsif, Jurnal, Al-Adl Vol. 9, No. 1, 2016.

Arianto Henry, Hukum Responsif dan Penegakan Hukum di Indonesia, Lex Jurnalica, Vol. 7, No. 2, 2010.

Asa Agam Ibnu, Pendidikan Menurut Ki Hadjar Dewantara dan Driyarkara, Jurnal Pendidikan Karakter UNY Yogyakarta, Vol. IX, No. 2, 2019. Bakker, A dan Zubair, A.C, Metodologi Penelitian Filsafat, Yogyakarta: Kanisius, 1990.

Hasanah Hasyim, Hermeneutik Ontologis-Dialektis-Georg Gadamer (Produksi Makna Wayang Sebagai Metode Dakwah Sunan Kalijogo), Jurnal At-Taqaddum, Vol.9, No.1, 2017.

Munir Misnal, Messianisme dalam Perspektif Filsafat Sejarah, Jurnal Filsafat UGM, Vol.36, No.1, 2004.

Sulaiman, Hukum Responsif: Hukum Sebagai Institusi Sosial Melayani Kebutuhan Sosial dalam Masa Transisi (Responsive Law: Law as a Social Institution to Servive of Social Need in Transition), Jurnal Hukum Samudra Keadilan, Vol. 9, No. 2, Cet. 2014.

Thesis:

Asa Agam Ibnu, Peran Mahkamah Konstitusi Mewujudkan Keadilan Substansial dalam Perspektif Hukum Responsif Philippe Nonet dan Philip Selznick (Studi Kasus Putusan Mahkamah Konstitusi Nomor 45/PHPU.D-VIII/2010, Yogyakarta: Tesis Filsafat Universitas Gadjah Mada, 2020. 